\title{
LOCAL AND SCIENTIFIC ECOLOGICAL KNOWLEDGE POTENTIAL AS A SOURCE OF INFORMATION IN A PERIURBAN RIVER, MEXICO CITY, MEXICO
}

\author{
CARO-BORRERO, A. P. ${ }^{1,2^{*}}$ - CARMONA-JIMÉNEZ, J. ${ }^{2}$ - VARLEY, A. ${ }^{3}$ - DE GARAY- \\ ARELLANO, G. ${ }^{4}-$ MAZARI-HIRIART, M. ${ }^{5}$ - ADAMS, D. K. ${ }^{6}$ \\ ${ }^{1}$ Posgrado en Ciencias del Mar y Limnología, Universidad Nacional Autónoma de México \\ (UNAM), Coyoacán, 04510 Ciudad de México, México \\ (e-mail: angelacaro@ciencias.unam.mx) \\ ${ }^{2}$ Departamento de Ecología y Recursos Naturales, Laboratorio de Ecosistemas de Ribera, \\ Facultad de Ciencias, UNAM, Coyoacán, 04510 Ciudad de México, México \\ (e-mail: jcj@ciencias.unam.mx) \\ ${ }^{3}$ Department of Geography, University College London (UCL), 26 Bedford Way, London \\ WC1H OAP, United Kingdom \\ (e-mail:a.varley@ucl.ac.uk) \\ ${ }^{4}$ Instituto Dr. José Luis María Mora, Plaza Valentín Gómez Farías \#12, Col. San Juan \\ Mixcoac, 03730 Ciudad de México, México \\ (e-mail:GGaray@institutomora.edu.mx) \\ ${ }^{5}$ Laboratorio Nacional de Ciencias de la Sostenibilidad, Instituto de Ecología, UNAM, \\ Coyoacán, 04510 Ciudad de México, México \\ (e-mail:mazari@unam.mx) \\ ${ }^{6}$ Centro de Ciencias de la Atmósfera, UNAM, Coyoacán, 04510 Ciudad de México, México \\ (e-mail:dave.k.adams@gmail.com) \\ *Corresponding author \\ e-mail: angelacaro@ciencias.unam.mx \\ (phone: +52-55-5622-4800, ext. 44747; fax: +52-55-5622-4828) \\ (Received 23 ${ }^{\text {rd }}$ Aug 2016; accepted $15^{\text {th }}$ Dec 2016)
}

\begin{abstract}
Rivers in large cities face management problems that could be addressed through the integration of scientific and local ecological knowledge. The objective of this article is to emphasize the importance of different sources of knowledge in management alternatives for periurban watersheds. Specifically, this is done through (a) use of oral sources and archives to document the historic relationship between local residents and their natural resources, and (b) technical evaluation of the quantity and quality of water in the sub-basin through the time. We analyzed, through the 19 unstructured interviews, local residents' knowledge related to water quantity and quality. Additionally, we analyzed historical river flow data and water quality reports. The results show that the relationship between the local inhabitants and the river has been governed by public policies of both exploitation and conservation. For the last century, the river was used as the main source of electric power for local industry, the collapse of which, led to the decline of the importance of the river in the perception of the locals. Analysis of historical river flow data reveals a slight decrease in flow despite a trend of somewhat lower precipitation. This discrepancy may be due to hydraulic infrastructure construction and uncontrolled extraction. We conclude that the integration of two kinds of knowledge present a great opportunity to test a monitoring system that incorporates the environmental features that were more accurately described by the local residents: water quantity and forest land use.
\end{abstract}

Keywords: environmental policies, Mexico City, illegal settlements, participative monitoring program, periurban river, water quality 


\section{Introduction}

Managing hydrologic resources has always been a priority in the establishment of human societies, requiring practices that are able to integrate the biophysical and socioeconomic components resulting from these interactions. Rivers, in particular, represent a challenge since based on the continuous interaction with human societies, as an important component of urban sustainability, particularly in preservation zones. As a feature of the environment, rivers are not bound to political divisions, nevertheless are highly sensitive to human activities, which in turn could alter the ecosystem outside certain political boundaries (Maass and Equihua, 2015). It is this interconnection between ecosystems and human beings at different spatial and temporal scales that shape socio-ecosystems (Maass, 2012). This concept emphasizes the importance of a coordinated management of water, land and related natural resources, maximizing social welfare without comprising sustainability and making local stakeholders a key part of the process (Bürgi et al., 2013; Molle and Mamanpoush, 2012; Swatuk and Motsholapheko, 2008).

The basis for developing an adaptive aquatic resource management strategy is the use of Local Ecological Knowledge (LEK) in scientific studies (Taylor and Loe, 2012). LEK is defined as the knowledge and perceptions from a particular group of people about local ecosystems and their interactions with the environmental, and how it is transmitted through the human generations using the oral communication' (Taylor and Loe, 2012; Gómez-Baggethun et al., 2012; Robertson and McGee, 2003; Olsson and Folke, 2001). This understanding is relevant because it facilitates the participation of local communities in land-use planning and decision making, since it empowers them and increases the likelihood that the management actions will be responsive to local concerns (Taylor and Loe, 2012; Alberti, 2010; Robertson and McGee, 2003). Additionally, it allows recognizing the capacity of resilience of the socio-ecosystem that, in turn, depends on the individual and collective experiences of local stakeholders (Fernández-Llamazares et al., 2015). Resilience, understood as the adaptation of the socio-ecological system to disturbances, which in practice can be any event that breaks the structure of the ecosystem and modifies the availability of resources, land use and/or the physical environment (Gómez -Baggethun et al., 2012).

Local ecological knowledge has been traditionally recorded in the form of questionnaires, by examining written historical documents, photography, maps and oral history, which become important in places where oral communication is the only way to transmit knowledge (Robertson and McGee, 2003). Oral history can be defined as ' $a$ structured conversation between two people, an interviewer pursuing a carefully defined line of inquiry, and a narrator with information that the interviewer seeks to acquire' (Fogerty, 2001). This tool offers the possibility of having a complementary management perspective, since written sources often reveal only official views (Fernández-Llamazares et al., 2015; Bürgi et al., 2013). Some studies show the contribution of LEK in improving the sources of information on ecosystems, that provide management alternatives accepted by local people, as a way to validate historical documentation, validation of scientific and local knowledge in a socioecological context and the potential for implementation participative monitoring systems (Bürgi et al., 2013; Terer et al., 2012; Gómez -Baggethun et al., 2012; Alberti, 2010; Giordano, et al., 2010; Raymond et al., 2010; Robertson and McGee, 2003). In this sense, local participation could be conceived also as the "result" of a process aiming to empower people and communities through a learning process leading to increased 
capabilities to self-manage their ecosystems (Fernández-Llamazares et al., 2015; Lawrence, 2006; Hayward et al., 2004).

In large cities, resource management through participative processes that involves LEK and public policies applied under a governance scheme in order to progress towards sustainability becomes a complex task, such is the case in Mexico City (Aguilar, 2008). The city is a good example of socio-ecosystem interaction because it still has periurban ecosystems that support it from the perspective of ecosystem services (ES) provision. In particular, the provision of water, in quantity and quality, is one of the most valued ES in a city with increasing urban growth and water management problems due to intensive aquifer exploitation and mismanagement of periurban rivers (Starkl et al., 2013; Legorreta, 2009).

Despite these environmental management problems, the city has 87,000 ha of natural areas designated as "Federal Conservation Zones" (CZ), which are mainly mountainous, forested regions that provide fundamental ESs to the city inhabitants (Caro-Borrero et al., 2015a). These areas are located in a rural-urban fringe, being characterized by several different changes and processes (Aguilar and Santos, 2011): a dispersal pattern of urban occupation for housing and infrastructure; an establishment of illegal settlements with precarious dwellings and lack of public services; extraction of building materials and surface water and groundwater; as well as alteration of river courses. The best preserved zone of the Basin of Mexico is located in the southwest region and is represented in part by the Magdalena-Eslava River sub-basin (PUECUNAM-GDF, 2008). This sub-basin provides one percent of the surface water supply for human consumption in Mexico City; however, the conservation of water resources is compromised due to land-use change by illegal urbanization, agriculture, and the lack of suitable public policies in different periurban and socio-ecological contexts (Wigle, 2010; Aguilar, 2008). Given the importance of the last surface rivers and the provision of water to human needs, it should be a priority to develop baseline studies that take into account the watershed's ecological present state, scientific opinion and historical socioecological knowledge. The objective of this article is to emphasize the importance of different sources of knowledge in management alternatives for periurban sub-basins and their conservation through (a) use of oral sources and archives to document the historic relationship between local residents and their natural resources, and (b) technical evaluation of the quantity and quality of water available in the sub-basin, both in the present and in the past. These hydrological parameters were selected because they are widely recognized and valued by people and data are available to compare the evolution in time and space.

\section{Mexico City's historic context and its relation with surface water and forests}

The Basin of Mexico, where Mexico City is located, has experienced deep social and environmental transformations since pre-Columbian times. The Mexican culture (or Aztec) settled in what was once a lacustrine system (Legorreta, 2009). In the southern area a highly productive agro-ecosystem was built, what is known as chinampas, consisting of artificial islands man made as extensions of soil laid upon branches and roots, secured by stakes anchored to the lake's bottom using Salix bonplandiana trees, thus allowing water to reach by capillarity the plants root system. The Mexica culture also created engineering structures such as the installation of aqueducts that doubled as a source of drinking water and served also as a flood control infrastructure, given the numerous rivers that fed the area (González-Reynoso et al., 2010). During the Spanish 
intervention many dykes and dams were built to contain the constant floods, although none proved to be very effective (Ezcurra, 1990). It was not until the $17^{\text {th }}$ century that a more permanent solution was implemented, transforming the basin in an irreversible way into the exorheic basin instead of an endorheic system, with the construction of a deep and extensive drainage system (González-Reynoso et al., 2010).

The new exorheic nature of the lake system allowed the expansion of human settlements and city`s growth, which has continued until the present day. Nevertheless, during the first decades of the $20^{\text {th }}$ century, there were still many green areas and areas of farmland fed by the numerous streams and rivers present in the Basin of Mexico. Many of these rivers were also used by the textile and paper industry from the early 1800 s to the mid $20^{\text {th }}$ century, when both industries started to decline due to river flow reduction and social activism with strikes at the industries. The decline of these industries coincided with a rapid urban growth process and by 1950, the city had spread beyond its political limits and invaded the adjoining state, with an exponential increase in population in the last 50 years. The demographic data shows in 2005 its whole metropolitan zone registered 19.2 million inhabitants (Aguilar, 2008). The increasing demand of water in quantity and quality for the population has led to disproportionate groundwater extraction and the importation of water from adjacent basins (Aguilar and Santos, 2011). This accelerated growth has exacerbated water management problems and promoted intubation of water courses and deforestation (Wigle, 2010), particularly in the $\mathrm{CZ}$ of the Magdalena-Eslava River sub-basin (Figure 1).

\section{Urban Area's Evolution Upon the Conservation Soil in Mexico City}

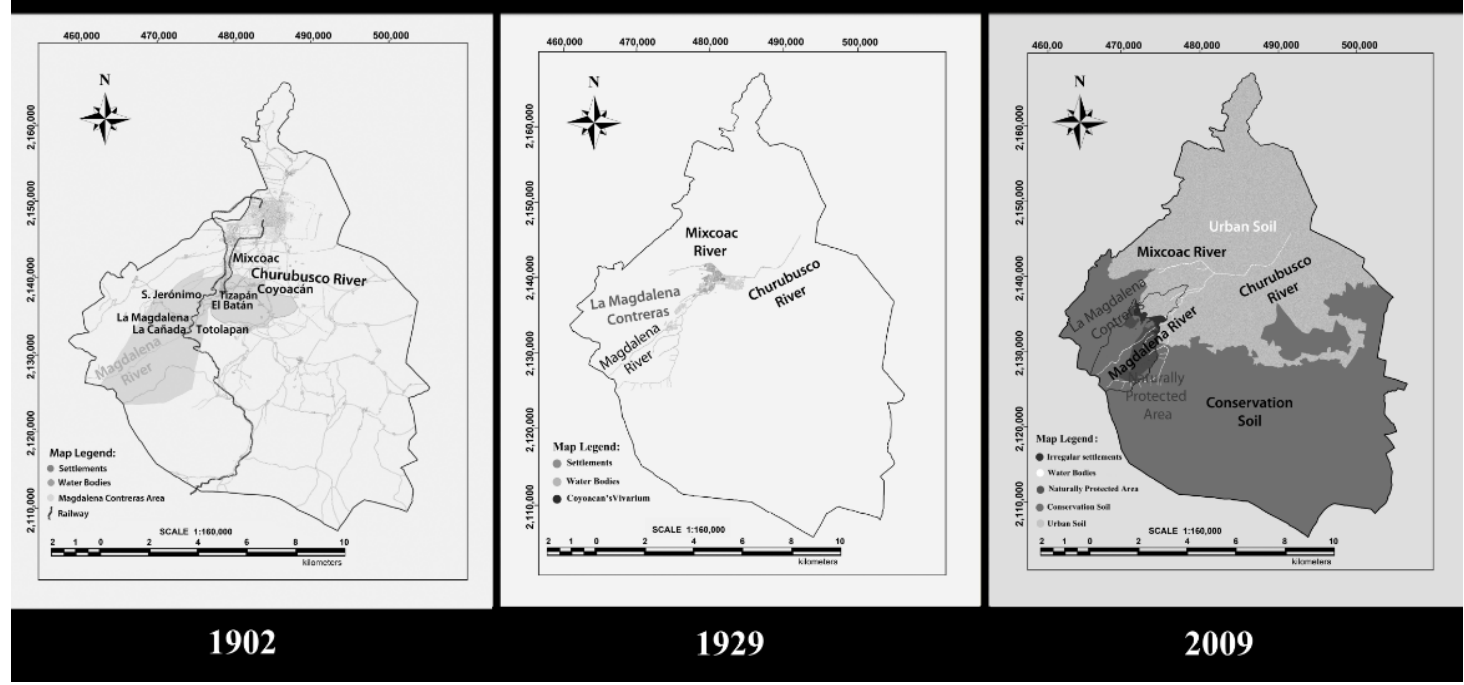

Figure 1. Major spatial demographic changes in Mexico City related to Conservation Zone and Magdalena-Eslava River sub-basin from 1902-2009.

\section{Mexico City at present}

The Mexico City has an average altitude of 2,240 $\mathrm{m}$ and an area of $1,495 \mathrm{~km}^{2}$ (Legorreta, 2009). Administratively, it is divided into an Urban Zone (UZ) with an area of $614.58 \mathrm{~km}^{2}(41 \%)$ and a Conservation Zone (CZ) with $872.95 \mathrm{~km}^{2}(59 \%)$. This latter zone comprises most rural areas to the south of the city and includes large portions of 
the forest mountain slopes (Aguilar, 2008). Of the 2.2 million people who live in the $\mathrm{CZ}, 700,000$ make direct use of it for their livelihood (i.e. agriculture, livestock breeding, extraction of non-timber forest products, etc.); they representing $8 \%$ of the total population in the entity that encompasses the central area of Mexico City (SEDATU, 2012). The land use policy consists of two regulations: (a) The General Program for Urban Development in Mexico City (2003), and (b) the Program for Ecological Planning (2003). However, an ambiguous interpretation and ignorance of social complexity, favors illegal occupations (Aguilar, 2008). For example, in the period 1970-1997, the CZ lost 239 ha of forest cover and 173 ha of agricultural land on an annual basis, while illegal settlements increased by 289 ha per year (Wigle, 2010).

The urban land uses within $\mathrm{CZ}$ mainly corresponds to 36 traditional towns that have existed in the Southwestern area of the city since ancient times (Aguilar, 2008). The Magdalena Atlitic community represented one of these traditional towns associated to the Magdalena-Eslava River sub-basin by since 1535 . Requests to be recognized as a community were made to the government in 1945, but they were not granted until 1975. Two thousand three hundred and ninety-three hectares were granted to the sub-basin common landowners through a Communal Rights Confirmation Presidential Act, which partially overlap with the natural protected area highlighted above. The Magdalena community is organized autonomously and represented legally by a president, secretary and treasurer. Only 250 of the actual 1779 registered landowners attend regularly the community general assembly, where collective issues are negotiated, discussed and decided. The Magdalena-Eslava River sub-basin is mostly a woodland area with a current cover of $67 \%$ well preserved forests (Ávila-Akerberg, 2009). The logging ban imposed by the area's inclusion in the $\mathrm{CZ}$ prohibits timber extraction (other than for ecological restoration purposes), but it does permit crop cultivation in some selected areas (SEDATU, 2012). However, the vast majority of residents work in the city and agricultural activities within the sub-basin have been progressively abandoned (Jujnovsky et al., 2012). In the Magdalena-Eslava River sub-basin, the provision of ES has been oriented mainly towards urban water supply and to some small extent to local ecotourism. However, uncontrolled tourism, unauthorized settlements and inefficient public policies have altered hydrological characteristics linked to the morphology of the sub-basin (Caro-Borrero et al., 2015a; Mazari-Hiriart et al., 2014). More recently the local government authorities have made some efforts to monitor and preserve the Magdalena-Eslava river sub-basin (PUEC-UNAM-GDF, 2009). Although, these efforts have been based on a combination of academic research and local government policy; paying very little attention to LEK and this has resulted in projects that have failed to achieve the desired objective of sub-basin conservations and river sanitation.

\section{Methods}

The scientific knowledge focused on the provision of water in quantity and quality, due to its historical importance since the emergence of Mexico City and its current relevance in the provision of water for a city with scarcity and a high population demand. The selection of basic criteria used to evaluate local ecological knowledge and ecological data were driven by an availability of official and academic information. Taking into account this limitation, we selected the water quantity and quality data as an ecological indicator of hydrological changes within the study area at a local scale (Table 1). 
Table 1. Basic criteria used to evaluate local hydrological and ecological knowledge evolution in the Magdalena-Eslava River sub-basin.

\begin{tabular}{|c|c|c|}
\hline & Indicator & Data source and method \\
\hline $\begin{array}{l}\text { Local ecological } \\
\text { knowledge }\end{array}$ & $\begin{array}{l}\text { Links to the river, industrial } \\
\text { development and community life }\end{array}$ & $\begin{array}{l}\text { Nineteen interviews using oral } \\
\text { history tool (Fogerty, 2001). } \\
\text { Selection of participants with } \\
\text { snowball technique (Neuman, } \\
\text { 2000). } \\
\text { Interviews analyses with } \\
\text { MAXQDA.11 software. }\end{array}$ \\
\hline \multirow[t]{4}{*}{$\begin{array}{l}\text { Historical and } \\
\text { scientific context }\end{array}$} & Water quantity & $\begin{array}{l}\text { One hydrometric station, } \\
\text { National Water Commission } \\
\text { (acronym in Spanish- } \\
\text { CONAGUA), 1976-2014. } \\
\text { (Caro-Borrero et al., 2015a; } \\
\text { Mazari-Hiriart et al., 2014) } \\
\text { Precipitation rate trends } \\
\text { Precipitation, 1998-2010. } \\
\text { Tropical Rainfall Measuring } \\
\text { Mission (TRMM) }\end{array}$ \\
\hline & Water quality & $\begin{array}{l}\text { One site, } 1945 . \\
\text { Historical Archive Water } \\
\text { (AHA, 1967). }\end{array}$ \\
\hline & & $\begin{array}{l}\text { Ten sites, 2008-2012. } \\
\text { Physical, chemical and } \\
\text { bacteriological data (Caro- } \\
\text { Borrero et al., 2015a; Mazari- } \\
\text { Hiriart et al., 2014). }\end{array}$ \\
\hline & Urban limits & $\begin{array}{l}\text { Maps } 1902,1903,1929 \text { and } \\
\text { 1936. Historical Water } \\
\text { Archive (AHA, 1967). }\end{array}$ \\
\hline
\end{tabular}

\section{Local ecological knowledge}

This study was defined as an unstructured conversation between an interviewer and local people who through personal experience, memories or association may possess relevant historical information regarding a particular fact, environmental characteristic or period of time (Fogerty, 2001). We conducted a series of unstructured interviews with local residents, defining a resident as someone who was born in the study area or 
had lived there for more than 30 years. The number of interviews carried out does not correspond to a numerically representative sample of the total population that inhabits the area, it is representative of the perception of key actors with an in-depth discourse on the memories of their life associated with the existence of the river. The interviewees contributed with pictures and some historic documents from the past 40 to 80 years, which were incorporated to the analysis. Between 2012 and 2014, nineteen interviews were conducted, lasting up to 2 hours each, based on an interview schedule that sought to focus responses on their knowledge of local socio-ecological context. The first interviewees selected were those who had participated in previous studies and could be contacted personally or by phone, and subsequently the snowball method was used to contact further interviewees (Neuman, 2000). The interviews were recorded and transcribed, then analyzed qualitatively with the MAXQDA.11 software program. The analysis centered on the following points: past and present relationship with the water resources (quantity and quality) and with the forest, rural life (understood as the daily activities that includes work, domestic activities, crops and local celebrations) and the influence of industrial development on the latter. These results were explored qualitatively, in order to assessment coincidences and integrated different sources of information: local knowledge, historical records and scientific monitoring data of water amount and its quality.

\section{Scientific knowledge: quantity and quality of water}

Historical analysis of the water quality was based on data obtained from 10 sampling stations from 2008 to 2012 period for the Magdalena River and from eight sampling stations from 2010 to 2012 for the Eslava River. We used the annual average per sampling site per year of monitoring. The sites were selected because they are part of a long-term academic monitoring system. (for sampling points geographical location, see Caro-Borrero et al., 2015a; Mazari-Hiriart et al., 2014; PUEC-UNAM-GDF, 2009; PUEC-UNAM-GDF, 2008). Physicochemical and bacteriological parameters (fecal coliform and fecal enterococci), were considered in order to assess water quality during the dry and rainy seasons. The analysis was compared with the maximum permissible limits established by the official water quality Mexican regulations for human use and consumption (NOM-127-SSA1-1994, fecal coliforms 0 CFU/100 mL) (DOF, 2000) and input of water to water bodies (NOM-001-ECOL-1996, total nitrogen $15 \mathrm{mg} / \mathrm{L}$, total phosphorous $5 \mathrm{mg} / \mathrm{L}$ ) (DOF, 1997), because we expected that local perceptions about the river were mainly associated with human consumption. Temporal differences in physicochemical parameters were assessed through a Kruskal-Wallis test, with normality confirmed by a Kolmogorov-Smirnov test. Differences between years were compared using a Mann-Whitney two-tailed test with $p \leq 0.005$ significance. All statistical tests were performed using SPSS V.13 statistical package (Softonic, 2004).

\section{Validation of flow rates and rainfall for the Magdalena-Eslava river sub-basin}

Water quantity was measure thought the historic flow rate data were available through official records provided by a local monitoring station of the National Water Commission (CONAGUA, Santa Teresa 26440 station). These data were used as a reference in the analysis, based on daily flow magnitude and variability for 38 years, recognizing two distinct flow periods that correspond to a dry and rainy season. The validation of official data used the precipitation rates that were obtained from the USA- 
Japan Tropical Rainfall Measuring Mission (TRMM) satellite observing system. The TRMM data product used in this analysis were the 3B42 V7 3-hour precipitation rates $(\mathrm{mm} / \mathrm{hr})$ with a spatial resolution of 0.25 by 0.25 degrees. These data can be downloaded from http://disc.sci.gsfc.nasa.gov/precipitation/documentation/ TRMM_README/TRMM_3B42readme.shtml. TRMM average three hours' precipitation rate data were chosen from the latitude/longitude grid point most representative of the Magdalena-Eslava River sub-basin (19.375 $\left.{ }^{\circ} \mathrm{LN}, 99.375^{\circ} \mathrm{LW}\right)$. Average three hours' precipitation rate data were analyzed from 1998 to 2010, which coincides with the discharge data from the Santa Teresa hydrometric station. Given the strong seasonal cycle, with precipitation most heavily concentrated from June to September, inclusive, monthly means were calculated for the 13 years' record period. These monthly mean precipitation rates were then subtracted from each of the data points (eight per day) for the corresponding months. The trend in rainfall intensity of this period of record was assessed employing the Mann-Kendall test with the NCAR Command Language (NCL). Likewise, the same procedure for removing the annual cycle in flow rate was also carried out for the daily flow rate data. This analysis was performed to validate the official data flow records with independent satellite data.

\section{Results}

\section{Local ecological knowledge}

Nineteen residents of the lower part of the sub-basin were interviewed: 12 women and seven men, aged between 57 and 92 years old. Of this group, two persons previously worked in the old textile and paper factories and six reported having relatives or friends who were also employed in the factories. The perceptions and knowledge expressed in the interviews mostly considered the Magdalena River as the fundamental element and their relation with: (a) rural life developed (includes daily activities in a rural area); questions on forest cover and reforestation activities were included under this heading, and (b) industrial, domestic and recreational activities were developed, including how these were connected to the quantity and quality of available water (Table 2). The results shows, until the 1960s (closing of the last mills in the area) the main factor affecting the forest was its exploitation by the paper mill, although, according to interviewees this industry did not lead to a forest area reduction:'There was never excessive logging. The main activity was dealing with tree diseases. The worst attack we had was in 1961 and the paper mill bought all the infected wood' (Interviews with María Isabel Olvera and Lucia Rosas, Mexico City, La Magdalena Contreras). Later, the paper mill closed down and imposed a ban on unsuccessful logging 'There were times when trucks came down all night loaded with wood. In the 1990s a logging company extracted wood saying that they had acquired logging rights for 100 years' (Interviews with Gregorio Valdez and Isabel Dolores Guzman, Mexico City, La Magdalena Contreras). 
Table 2. Evaluation of the perceptions of interviewees from the Magdalena-Eslava river subbasin using the MAXQDA program coding system.

\begin{tabular}{|c|c|c|}
\hline Analysis code & Perception & $\begin{array}{l}\text { Number of people } \\
\text { who mentioned it }\end{array}$ \\
\hline \multicolumn{3}{|l|}{ Forest } \\
\hline \multirow{3}{*}{$\begin{array}{l}\text { Perception of the } \\
\text { forest's current status }\end{array}$} & Existence of reforestation efforts & 8 \\
\hline & Illegal logging contributes to forest losses & 6 \\
\hline & $\begin{array}{l}\text { The current forest cover is less now than } \\
\text { when the factories were operational } \\
\text { (before 1968) }\end{array}$ & 11 \\
\hline \multirow[t]{2}{*}{ Forestry legislation } & Governmental control of logging & 5 \\
\hline & $\begin{array}{l}\text { Protected area status helps prevent illegal } \\
\text { logging }\end{array}$ & 4 \\
\hline \multicolumn{3}{|l|}{ Water quantity } \\
\hline \multirow[t]{2}{*}{ Present quantity } & $\begin{array}{l}\text { Flow rate is lower now than when the } \\
\text { factories were operational }\end{array}$ & 17 \\
\hline & The river dries up in the dry season & 11 \\
\hline \multirow{4}{*}{$\begin{array}{l}\text { Reasons for decrease } \\
\text { in flow rate }\end{array}$} & Caused by dam building & 1 \\
\hline & Government diverts water to other basins & 8 \\
\hline & It used to rain more & 6 \\
\hline & Unauthorized settlements in the basin & 7 \\
\hline \multicolumn{3}{|l|}{ Water quality } \\
\hline \multirow[t]{3}{*}{ Current water quality } & Good in the upstream area of the sub-basin & 8 \\
\hline & $\begin{array}{l}\text { Poor in the downstream area because of: } \\
\text { Domestic sewage } \\
\text { Garbage dumping } \\
\text { Dead animals } \\
\text { Human and animal feces }\end{array}$ & $\begin{array}{l}10 \\
7 \\
3 \\
3\end{array}$ \\
\hline & $\begin{array}{l}\text { Current water quality is worse than before } \\
\text { the factories closed }\end{array}$ & 16 \\
\hline $\begin{array}{l}\text { Water quality in and } \\
\text { before the } 1960 \mathrm{~s}\end{array}$ & $\begin{array}{l}\text { Excellent quality (clean and clear water) } \\
\text { before the factories were established }\end{array}$ & 18 \\
\hline
\end{tabular}




\begin{tabular}{|c|c|c|}
\hline & Uses of good quality water: & \\
\hline & Drinking & 9 \\
\hline & Bathing & 8 \\
\hline & Laundry & 11 \\
\hline & Crop irrigation & 1 \\
\hline & $\begin{array}{l}\text { The river was contaminated below the } \\
\text { factory area because of: }\end{array}$ & \\
\hline & Garbage dumping & 3 \\
\hline & Textile dyes and chemicals & 2 \\
\hline River uses & & \\
\hline Present & Tourism (trout fishing and trekking) & 12 \\
\hline & $\begin{array}{l}\text { Religious festivities (related to catholic } \\
\text { celebrations mostly) }\end{array}$ & 9 \\
\hline $\begin{array}{l}\text { Perception of risk } \\
\text { associated to the }\end{array}$ & $\begin{array}{l}\text { Landslides involving unauthorized } \\
\text { settlements }\end{array}$ & 6 \\
\hline & Floods in the lower part of the basin & 5 \\
\hline $\begin{array}{l}\text { Responsibility for } \\
\text { forest and river } \\
\text { degradation }\end{array}$ & $\begin{array}{l}\text { Unauthorized settlements allowed by: } \\
\text { Land owners } \\
\text { Local government }\end{array}$ & $\begin{array}{l}5 \\
7\end{array}$ \\
\hline
\end{tabular}

\section{Local and scientific knowledge: quantity and quality of water}

The general perception of the local residents on water amount is that it was more plentiful before the factories ceased to operate, between 1963 and 1968, than it is today (Table 2). There are fewer streams feeding into the river and the flow has been reduced. As the residents put it: 'We miss the murmur (sound) of the river' (Interviews with Maria Isabel Olvera and Lucia Ramos, Mexico City, La Magdalena Contreras); 'the river used to carry a lot more water; there was a lot more water before the water treatment plant was built, which has taken half of the river flow from here up to the first dynamo' (Interview with Gregorio Valdez, Mexico City, La Magdalena Contreras) [Dynamo is an electrical generators that delivered power using the water flow of the river for both textile and paper industry. At the present time only remained the abandoned dynamos constructions that are out-of-use]. Local ecological knowledge shows that most of the interviewees perceive a tendency for the amount of water in the river to decrease, mostly because the river now ceases to flow in the downstream area during the dry season. On the other hand, the quantifiable data evaluation shows that the superficial flow annual average has remained constant in the last 38 years, with variations related to seasonal changes in water flow management. Leaving as a consequence an excessive runoff during rainy season and a drastically decreasing during the dry season. These observations are similar to those expressed by the residents, pointing to the local population's potential role in monitoring. 
Water quality issues have been a worry in the river for decades, although the interviewees showed less concern about contamination that the factories may have caused and, in some cases, they even considered it beneficial for the local people. For example, the residues of dyes used by the factories that were returned to the river were used for dyeing clothes and hair. Water quality reports from four factories that were discharging wastewaters into the Magdalena River in the 1960s show that the water was slightly acidic ( $\mathrm{pH}$ 6.4), containing abundant organic matter, was murky and colored (gray, blue, purple or yellow) with a sulfuric acid odour, and was deemed not fit for human or animal consumption and in some cases not even for agricultural irrigation (AHA, 1967). Current perceptions of quality are related to contamination coming mostly from human settlements (authorized or unauthorized) lacking connections to the sewerage system. The interviewees mentioned that they do not use water from the river, although they did acknowledge that water quality was better upstream: 'For the last 20 years I have been forbidding my son to swim in the river because is not the same as before; he had a severe eye infection. With the dynamos the water was intercepted; when the water was released the river was cleaned and because of that the colored water produced by the factory discharges was flushed away and there were no infections' (Interview with María Isabel Olvera, Mexico City, La Magdalena Contreras).

According to the human use and consumption, there is an increase in the number of enterobacteria found at the upstream. In the middle section of the sub-basin, there is evidence that the number of enterobacteria decreases and thus water quality is improved, which is a sign of the river's self-purification ability, considered a regulation ecosystem services. In the downstream section, water quality is again compromised because of sewage discharge, shown by the rise in enterobacteria numbers in which the self-purification is exceeded (Figure 2).

The Kruskal-Wallis test showed a significant variation in the physicochemical and bacteriological parameters in at least one year of sampling in each river $(p=0.0-0.005)$. The Mann-Whitney test detected significant differences in total nitrogen $(p=0.0-0.022)$ and total phosphorous ( $p=0.0-0.009)$ in the Magdalena River between 2008 and 2009 and in enterobacteria ( $p=0.0-0.001)$ between 2011 and 2012. In general, concentrations in the $\mathrm{UZ}$ and $\mathrm{CZ}$ were similar and displayed similar tendencies over time with a rise in total nitrogen observed in 2012 (Figure 2). There were significant differences in dissolved oxygen concentration $(\mathrm{p}=0.008)$ and fecal coliforms $(p=0.032)$ in the Eslava River between 2010 and 2012 (Figure 2).

\section{Official data validation: analysis of rainfall versus discharge}

According to the results from the Tropical Rainfall Measuring Mission (TRMM) satellite data, precipitation intensity has decreased by $-0.00148 \mathrm{~mm} / \mathrm{hr} / \mathrm{year}$. This decreasing trend in precipitation was shown to be significant using the Mann-Kendall test at the $95^{\text {th }}$ percentile. By contrast, the flow rate in the Magdalena River increased by $0.007 \mathrm{~m}^{3} / \mathrm{sec} /$ year, this being significant to the $99^{\text {th }}$ percentile. That is, rainfall rates appear to decrease over the basin and elevated terrain, yet there is an increase in the Magdalena River flow (Figure 3). 


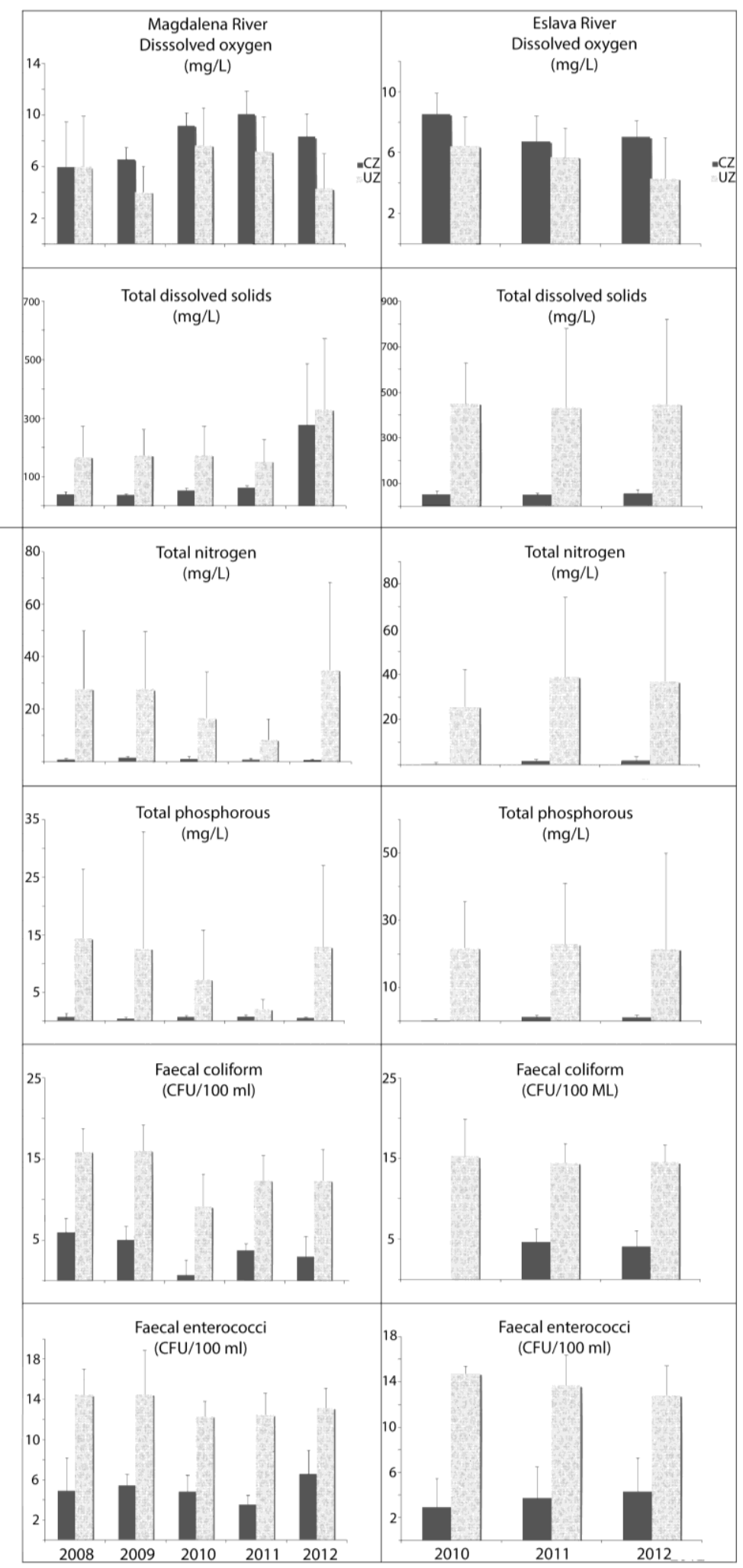

Figure 2. Representative physicochemical parameters with the highest annual average variations. Left side: Magdalena River ( $n=30$ corresponds to five sampling point in the $C Z$ and five in the UZ, mean $\pm S E$, five-year sampling). Right side: Eslava River ( $n=12$ corresponds to five sampling point in the $C Z$ and three in the $U Z$, mean $\pm S E$, three-year sampling). CZ:

Conservation Zone. UZ: Urban Zone.

APPLIED ECOLOGY AND ENVIRONMENTAL RESEARCH 15(1): 541-562.

http://www.aloki.hu • ISSN 15891623 (Print) • ISSN 17850037 (Online)

DOI: http://dx.doi.org/10.15666/aeer/1501_541562

(c) 2017, ALÖKI Kft., Budapest, Hungary 

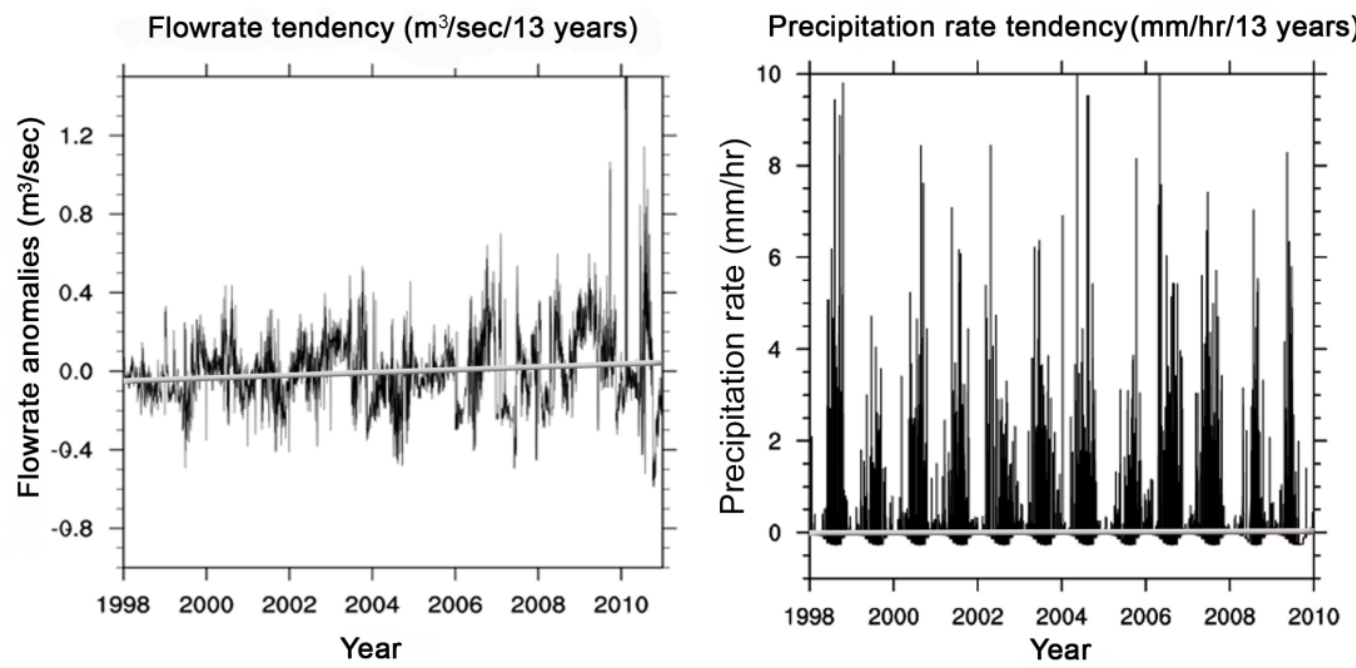

Figure 3. Comparison of the flow rate tendencies obtained from official data collected by local government and precipitation records obtained from the satellite system between 1998 and 2010.

\section{Discussion}

In Mexico City, more than $15 \%$ of the $\mathrm{CZ}$ has been affected by urban growth on what was forested and agricultural land, and it is predicted that by 2020, the $32 \%$ of CZ will have been occupied by urban growth (Schteingart and Salazar, 2005). Currently, unauthorized settlements are the main cause of forest loss, land use change and increased demand for domestic water supplies and drainage (Aguilar, 2008). Although, Mexico City has some public policies for conservation like the Environmental Agenda which aimed "protecting conservation land as a key space for the environmental equilibrium of the city, through protecting its ecosystems as well as preserving its natural flora and fauna in order to ensure the existence of environmental services' (GDF, 2007). One of the key strategies was the '[...] implementation of normative and regulatory tools, in terms of land use in conservation zone, for the control and ordering of irregular settlements [...]'. In the same way, the Green Plan objective states: '...rescue conservation zone as a key space for the ecological equilibrium of the city...' through several strategies that included '[...] zero growth of irregular settlements [...]' in the CZ (GDF, 2009). When searching for management and conservation alternatives in the Magdalena-Eslava River sub-basin, LEK suggests a weak relationship between the residents and the natural resources in their area, in particular with water, although, water provision and drainage coverage in the CZ is highly deficient (Aguilar, 2008). The poor results can be due to the utilitarian view of the river, expressed by local people through their relationship with the river when local factories were operating. Here, it is relevant to point out the "tragedy of the commons" (Ostrom, 1991), because the subbasin is important for the entire city (inhabitants' health and socio-economic development) and only some of the landowners have the full weight of the conservation on their shoulders. 


\section{Trends towards change within the sub-basin: water quantity}

As LEK showed, the use of the river as an energy source for the factories was not a cause of significant reductions in water quantity. It did, however, have an impact on the river bank structure and stream bed. Local residents are aware and interested in giving qualitative tracking of these impacts and, as such, they could be persuaded to engage in a potential community monitoring, but another scenario is possible too. The local inhabitants can be aware 'passively' and finally not directly engaged actively in monitoring activities. In this sense, the awareness is not the only factor that plays a role in order to start the community monitoring program; an environmental education program that integrates local and scientific knowledge should be a requirement (Fernández-Llamazares et al., 2015). However, the effects of flow rate reductions by hydroelectric infrastructure such as dynamos and water extraction channels, could not be assessed either via LEK or by historical records. It could potentially cause habitat fragmentation and negatively affect biodiversity, as has been recorded elsewhere due to gabion dams, that have been constructed in the upper sub-basin (Caro-Borrero et al., 2015a; Wohl, 2006). Additionally, to the construction of gabion dams promoted by the local government in the 1990s as a flood control measure and the construction in 2011 of a marginal sewer in the river bed which was intended to transport sewage from unauthorized settlements upstream (PUEC-UNAM-GDF, 2009). Seasonal low surface runoff is a consequence of the proximity with the UZ, and of unauthorized and authorized settlements occupying woodlands and agricultural lands, e.g. because of the paved effect affecting groundwater recharge, which by the type of rock and soil, naturally is less a three percentage in the sub-basin (Jujnovsky et al., 2012). The observed surface runoff values in this case are $19 \mathrm{~mm}$ in areas currently undergoing urban growth and $325 \mathrm{~mm}$ in well-preserved areas (Caro-Borrero et al., 2015a; Jujnovsky et al., 2012).

According to local residents, changes in flow rates were attributed to water extraction operations by the government in addressing water demand in other areas of the city. The latter causes a feeling of uncertainty on the actual local river water distribution. Due to this situation, the locals solve their water supply by informal means: for example, small spring water extraction, carrying water from distant sources, public taps, or buying it from trucks (Aguilar, 2008). Analysis of official records concerning historical flow rates shows that in the period from 1990 to 2010 , natural flow became regulated, with a recorded flow rate average of $0.70 \mathrm{~m}^{3 /} \mathrm{s}$ but $0.67 \mathrm{~m}^{3 /} \mathrm{s}$ between 2002 and 2003, when the hydraulic works on the river bed became more evident (MazariHiriart et al., 2014). Average monthly flow rate values show that the natural rate remained unchanged until 1989 with the expected rise during the rainy season and lower values in the dry season. However, observations from 1990 onwards show a constant flow rate across the different seasons, a clear indication of flow regulation activities (Mazari-Hiriart et al., 2014). This trend is also confirmed by the annual average flow rate data and the local residents' perceptions. Local residents' perceptions of the effects of hydraulic infrastructure and city water extraction on flow rates and water baseline are quite close to what was observed in reality and as such they can be valued as potential monitoring agents, as long as they decide to be active agents and not just passive observers (Giordano et al., 2010).

The comparison of flow rate and precipitation reveals that precipitation trends have little effect on flow rate reductions, and, as such, there is no evidence of climateinduced change. On the contrary, the analysis shows a slight increase in flow-rate trends 
and a decrease in precipitation amount. The latter may be a consequence of a higher runoff caused by the presence of non-porous materials, a sign of urban expansion in the CZ (Wohl, 2006). This means that sub-superficial and deep-water infiltration may be compromised, affecting the perennial character of the Magdalena-Eslava River system. As such, hydraulic infrastructure and urban expansion have a great impact on the structure and ecosystem health, taking water quality and quantity parameters to the limit, hence presenting a challenge when designing environmentally and socially sustainability public policies in the short and long term and compressing the ecosystem services the river provides to the city (Brauman et al., 2007).

\section{Water quality}

Local residents interviewed did not perceive historical water contamination caused by the factories as a problem; some seemed to be oblivious to it and others even took advantage of it: 'Sometimes water was dyed in different colors, mostly red and blue, so when the water was blue, we washed our clothes in it to color them and when it was red I dipped my hair in to dye It' (Interview with Lucía Rosas, Mexico City, La Magdalena Contreras). Nonetheless, these dyes and chemicals, a byproduct of textile companies, were an evident sign of contamination (AHA, 1967). The industrial activity that took place in the Magdalena River led to deforestation and water chemical contamination that eventually caused complaints, not only about environmental problems but also because the river water could not be used for other activities such as agriculture and livestock (Barbosa-Cruz, 2005).

The present analysis of monitoring water quality data shows that the construction of perimeter drainage infrastructure in the Magdalena River greatly reduced the river's self-purification ability. During 2011 and 2012, an increase in organic matter and enterobacteria in the UZ was recorded (Figure 2), despite the perimetral drainage that was supposed to reduce water contamination from human waste originating in human settlements lacking adequate sewerage. In the same period, the Eslava River was also altered by perimetral and urban area drainage construction, with a similar outcome to the Magdalena River. As such, recovery measures undertaken in both rivers were unsuccessful and even unlawful since local regulations forbid permanently altering the natural flow, and riverbed of streams and land use change in the CZ (DOF, 2000). The failure of the perimetral drainage system explains the inefficiency of outdated river control practices, which do not incorporate an integral environmental approach, but it might also be a product of technical problems in designing the perimeter drainage system mostly due to hydro-geomorphological characteristics of the sub-basin (PUECUNAM-GDF, 2009). The elevated nutrients and microbiological contaminants, altered channel hydro-geomorphology and stability, and reduced biotic richness and increased dominance of tolerant species requires sub-basin scale solutions. A primary requirement of reversing the periurban stream is the management of wastewater effluent. The Mexico City authorities have also been unsuccessful in trying to implement integrated sustainability policies (such as Payments for Ecosystem Services Program, CaroBorrero et al., 2015b), probably because they have neglected LEK, as budget deficits and law enforcement (e.g. the urban expansion on CZ) get in the way of political goals at federal, regional and local level of goverment implementation (Aguilar and Santos; 2011; Wigle, 2010). A clear example of this situation was the intervention on the riverbed with the perimetral drainage by the regional government through the Mexico City Water System local authority (SACMEX, for the acronym in Spanish), the 
hydraulics intervention changes the hydrological pattern of the river and that has serious consequences for the functioning of the aquatic ecosystem and biological communities (Caro-Borrero et al., 2015a; Mazari-Hiriart et al., 2014).

\section{Precipitation and flow rate trends: evolution of the Magdalena-Eslava socio- ecosystem}

Local residents' testimonials emphasize that the river has lost relevance in everyday life because there are no major practical uses to it, like when the factories operated and they got jobs. This perception can, to some extent, be linked to the relationship between water, forests and local economic development, due the rural inhabitants, in occasions, they seem to be more "sensitivity", it is surely more likely to be because their livelihoods depend more directly on environmental quality (Silvano et al., 2005). The mills and other industries relying on the river for their functioning were until 1960's the main economy drivers in the area and for that reason the river was perceived as useful (Acosta-Colín, 2001).

As the result of continued urban expansion over the past 50 years (Figure 1), the subbasin has been almost entirely absorbed into the city. This is a common problem in the city, where elevated areas are becoming part of the built environment despite the local regulations, including the ecological planning decree that forbids human settlement in the CZ (Starkl et al., 2013; Wigle, 2010; Aguilar, 2008). During the last 30 years of industrial operation in the area, two ordinances were issued to protect the forested areas, but these have only hindered management efforts, because of the contradictions in the size of the protected area resulting in the reduction of forests and even the intervention of the riverbed (Jujnovsky et al., 2012). However, the General Program of Ecological Planning of Mexico City, issued in 2000, established a Protected Forest Zone in an area of 215 ha from the middle section of the basin up to the UZ (Jujnovsky et al., 2012).

We suggest the use of socio-ecosystem framework, as an essential element to empower local residents and landowners in order for them to get identified once again with their environment (Maass and Equihua, 2015). For local inhabitants the identity is deeply rooted to a single location and their interest is to preserve their place histories, traditions and identities (Starkl et al., 2013; Aguilar, 2008). For example, the local residents express an interest in rescuing the river and recognizing one again its usefulness as a symbol of progress, and also to use it as a direct source of water: 'When the factories ceased operations the river died, outsiders began to arrive to the community and the river was no longer the main development driver in the area. People switched jobs and community unity was lost. People even stopped using public laundry facilities supplied by river water and stopped doing their laundry at the edge of the river' (Interview with Isabel Dolores Guzman, Mexico City, La Magdalena Contreras). However, in the Magdalena-Eslava River system there are two particularly conflictive social groups. The first of them is formed by the original residents with legal ownership rights and the second is formed by illegal settlers. The original residents who lived from the land showed LEK, in general acquired through experience and oral tradition. Unauthorized settlers arrived from other rural regions and since they have no legal rights most of the times they are overlooked when implementing environmental management policies. Urban sprawl in many cases been favored by the landowners themselves, the illegal sale of land is theoretically for conservation or agriculture for self-consumption. In this way, it has been the massive sale of forest land to people highly marginalized (Aguilar, 2008; Varley, 1985). With respect to the Mexico City's 
land-use policy, some authors shows that it has been internally inconsistent, failing to take unauthorized settlements into account in the sustainable policies development for providing solutions to ecological degradation problems (Aguilar and Santos, 2011).

These unauthorized settlements are not anti-social elements, they simply need somewhere to live, but they are a convenient scapegoat for everything that goes wrong. This adds to the social injustice that led to their marginalization in the first place (Aguilar and Santos, 2011). Unauthorized residents might represent the largest potential for change when designing sustainable strategies, because they live within the $\mathrm{CZ}$ and may be the only ones capable of generating positive action and control for the forest and river conservation, as it has happened in other areas of the $\mathrm{CZ}$ with these land-use management problems (Wigle, 2010). However, these strategies requires that the landuse policies be consistence with urban and conservation zone designation (Aguilar and Santos, 2011; Aguilar, 2008).

Main threats to the $\mathrm{CZ}$ are associated with the dynamic of land use changes that has major repercussions for the environmental natural conditions of the CZ (Wigle, 2010; Aguilar, 2008). These processes represent a big challenge to integrate the LEK and scientific knowledge, because different social actors have had different ways of acquiring knowledge and not in all the occasions respond to an ancestral tradition and the same motivations to conserve the natural resources (Raymond et al., 2010). Then, iterative processes are required to consolidate and integrate knowledge, but these processes require continuous coordinated work between the local and scientific community (Giordano et al., 2010), within a confidence relationship that takes time to acquire. The testimonials gathered in this fashion, are enable to use in order to

capitalize on the experience of local residents and thus become useful when planning sustainable urban development's (Wall, 2014; Calvo-Iglesias et al., 2006). In this sense, the possible solution could be focus on mitigation actions, for example, thought the participative monitoring programs (Giordano et al., 2010), as a first step, rather than eliminating the impact of unauthorized settlements on conservation zone (Wigle, 2010), because this would be an unrealistic solution.

\section{Conclusions}

Although, a longer period of time, data and more deep analyses of community perceptions is needed for a more complete view, this work shows that local ecological knowledge is a useful tool to be incorporated into conservation and rescue of river basins management strategies, mainly because of the fundamental role local residents play in relation to the success of public policies implementation. Figure 4 shows the conceptual scheme summaries the mainly topics to consider in order to improve the design of public policies based on our results and literature.

In the Magdalena-Eslava River sub-basin, local residents' perception of water quality differs from what historical records show. While residents did not recognize contamination, such as the textile dyes that were even considered as an advantage, official records show that there were serious contamination issues in the area. Which can result from the implementation of public policies that encouraged the exploitation of the river by factories and at present limit the contact and use by the local people as a conservation policy. 


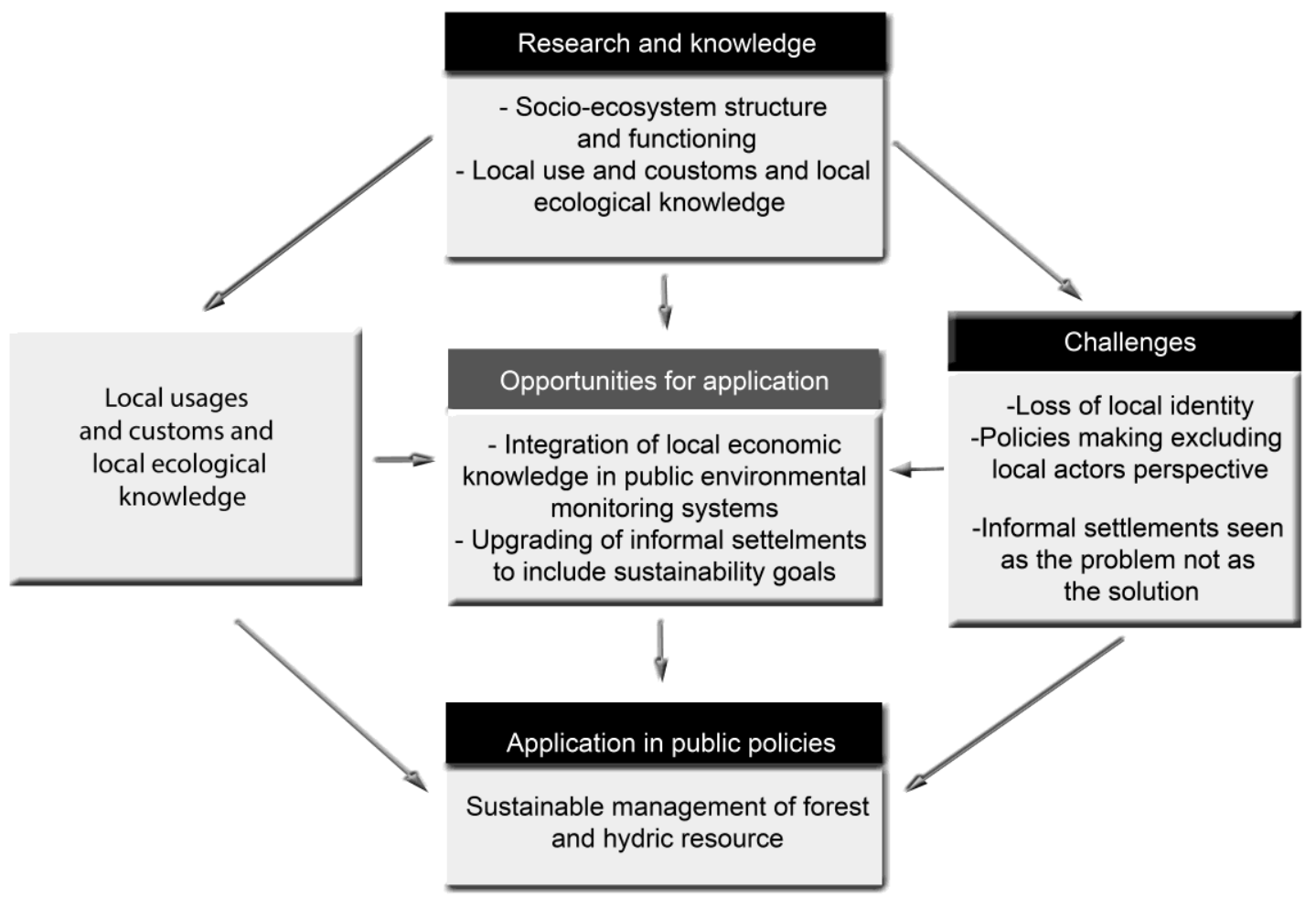

Figure 4. Conceptual framework that includes the socio-ecosystem relationship with local ecological knowledge (Modified from Terer et al., 2012).

The analysis of official data revealed a slight trend towards increasing flow rates, whereas precipitation records show a trend towards somewhat lower rainfall rates. This might be explained by the proliferation of hydraulic infrastructure, especially unregulated water extraction and the regulation in surface runoff.

In order to achieve social, economic and environmental progress in the city, it is essential to consider the future of unauthorized settlements; it will otherwise be impossible to offer a comprehensive solution. Land use change, the conflicts between ownership rights and environmental needs result in a problem that is not only environmental, but also social and due to the complexity, with economic implications. More inter and transdisciplinary studies are required in the near future in the area. This case study is an example of the lack of clear public policies that which result in missing the opportunity to conserve and sustainably use related to a vital resource such as water.

This article has discussed two types of knowledge that may be useful in understanding the Magdalena-Eslava River sub-basin: local ecological knowledge and scientific knowledge. The integrations of these two presents a great opportunity to test a monitoring system that incorporates the environmental features that were more accurately described by the local residents: water quantity and forest land use. This could in practice translate into more job opportunities for authorized and unauthorized residents alike, as well as improving the chances of successful recovery strategies for the ecosystem services qualitatively and quantitatively provided by the river when including biological and physicochemical parameters identified in previous studies. 
Local ecological knowledge is a good starting point as a strategy to understand the perceptions, visions and values, such as patrimony and heritage, implicit in the socio-ecological evolution, and taking into account the scientific knowledge in order to have a big picture about the structure and function, including quality and quantity of the aquatic ecosystem and translate it into ecosystem services potential, particularly in a periurban context of a megacity. Then, both types of knowledge are necessary because they validate each other, when the conservation policies application requires both the scientific knowledge as a background and the LEK to understand the socio-ecological context in which conservation measures intend to be implemented.

Acknowledgements. The authors thank Edgar Miguel Caro (Posgrado en Artes Visuales y Diseño UNAM) for the elaboration and edition of maps, Ann Grant for reviewing and offering critical suggestions and improving the manuscript, and Pablo Brauer for English-language editing. We are also grateful for the financial support provided by the National Council of Science and Technology (CONACYT in the Spanish acronym) through the Angela Caro Borrero Doctoral Scholarship and for support from the Posgrado en Ciencias del Mar y Limnología, UNAM and Instituto Mora through the undergraduate students' cooperation in the interviewers: Maricela Barrera, Edgar Reyes Espinosa, Andrea Sienra and Isela Rivero.

\section{REFERENCES}

[1] Acosta-Colín, S.L. (2001): Las tierras comunales de La Magdalena Contreras: una naturaleza socializada.-Tesis de Pregrado en Geografía. Facultad de Filosofía y Letras. Universidad Nacional Autónoma de México, México, D.F. México.

[2] Aguilar, A.G. (2008): Peri-urbanization, illegal settlements and environmental impact in Mexico City. -Cities 25: 133-145.

[3] Aguilar, A.G., Santos, C. (2011): Informal settlement's needs and environmental conservation in Mexico City: An unsolved challenge for land-use policy. -Land Use Policy 28: 649-662.

[4] Alberti, M. (2010): Maintaining ecological integrity and sustaining ecosystem function in urban areas. -Environmental Sustainability 2: 178-184.

[5] Archivo Histórico del Agua (AHA): Fondo: Aprovechamientos Superficiales, Caja 599, Epx 8711, FS 69-72, 1967.

[6] Ávila-Akerberg, V.D. (2009): Forest quality in the southwest of Mexico City. Assesment towards ecological restoration of ecosystem services. PhD Thesis, Faculty of Forest and Environmental Sciences, Albert -Ludwigs- Universitat, Germany.

[7] Barbosa-Cruz, M. (2005): Los límites de lo "público". Conflictos por el uso del caudal del río Magdalena en el valle de México durante el porfiriato. -Revista Historias 61:2742. http://www.estudioshistoricos.inah.gob.mx/revistaHistorias/?p=436

[8] Brauman, K.A., Daily, G.C., Duarte, T.K., Mooney, H.A. (2007): The nature and value of ecosystem services: an overwiev highlighting hydrologic services. -Annual Review of Environment and Resources 38: 67-98.

[9] Bürgi, M., Gimmi, U., Stuber, M. (2013): Assessing traditional knowledge on forest uses to understand forest ecosystem dynamics. -Forest Ecology and Management 289:115122.

[10] Calvo-Iglesias, M.S., Crecente-Maseda, R., Fra-Paleo, U. (2006): Exploring farmer's knowledge as a source of information on past and present cultural landscapes a case study from NW Spain. -Landscape and Urban Planning 78:334-343.

[11] Caro-Borrero, A.P., Carmona-Jiménez, J., González-Martínez, T., Mazari-Hiriart, M. (2015a): Hydrological evaluation of a peri-urban stream and its impact on ecosystem services potential. -Global Ecology and Conservation 3: 628-644. 
[12] Caro-Borrero, A.P., Corbera, E., Neitzel, K.C., Almeida, L., (2015b): "We are the city lungs": payment for ecosystem services in the outskirts of Mexico City. -Land Use Policy 43:138-148.

[13] Diario Oficial de la Federación (DOF). (1997): Norma Oficial Mexicana. NOM 001ECOL-1996. Que establece los límitoes máximos permisibles de contaminantes en las descargas de aguas residuales en aguas y bienes nacionales. México, D.F. México.

[14] Diario Oficial de la Federación (DOF). (2000): Norma Oficial Mexicana. NOM $127-$ SSA1-1994. Salud ambiental, agua para uso y consumo humano-Límites permisibles de calidad y tratamientos a que debe someterse el agua para su potabilización. México, D.F. México.

[15] Ezcurra, E. (1990): De las chinampas a la megalopolis: El medio ambiente en la Cuenca de México. Fondo de Cultura Económica, México, CDMX.

[16] Fernández-Llamazares, A., Díaz-Reviriego, I., Luz, A.C., Cabeza, M., Pyhälä, A., ReyesGarcía, V. (2015): Rapid ecosystem change challenges the adaptative capacity of local environmental knowledge. -Global Environmental Change 31: 272-284.

[17] Fogerty, J.E. (2001): Oral history a guide to its creation and use-In: Egan, D., Howell, E.A. (Eds.), The historical ecology handbook: A restorationist's guide to reference ecosystems. Oxford Unviversity Press, Washington DC, pp. 101-120.

[18] Giordano, K., liersch, S., Vurro, M., Hirsch, D. (2010): Integrating local and technical knowledge to support soil salinity monitoring in the Amudarya river basin. -Journal of Environmental Management 91: 1718-1729.

[19] Gobierno del Distrito Federal (GDF). (2007): Agenda ambiental de la Ciudad de México. Programa de Medio Ambiente (2007-2012). Secretaria de Medio Ambiente, GDF. Mexico City.

[20] Gobierno del Distrito Federal (GDF). (2009): Plan Verde, Ciudad de México. Secretaría de Medio Ambiente, GDF. Mexico City.

[21] González-Reynoso, A.E., Hernández-Muñoz, L., Perló-Cohen, M., Zamora-Saenz, I. (2010): Rescate de ríos urbanos. PUEC-UNAM-GDF. México, D.F.

[22] Gómez-Baggethun, E., Reyes-García, V., Olsson, P., Montes, C. (2012): Traditional ecological knowledge and community resilience to environmental extremes: A case study in Doñana, SW Spain. -Global Environmental Change 22: 640-650.

[23] Hayward, C., Simpson, L., Wood, L., (2004): Still left out in the cold: problematising participatory research and development. -Sociologia Ruralis 44(1): 95-108.

[24] Jujnovsky, J., González-Martínez, T., Cantoral-Uriza, E., Almeida-Leñero, L. (2012): Assessment of water supply as an ecosystem service in a rural-urban watershed in southwest Mexico City. -Environmental Management 49(3):690-702.

[25] Lawrence, A. (2006): 'No personalmotive?' _Volunteers, biodiversity, and the false dichotomies of participation. -Ethics,Place and Environment 9(3): 279-298.

[26] Legorreta, J. (2009): Ríos, lagos y manantiales del valle de México. Universidad Autónoma Metropolitana. México, D.F.

[27] MAXQDA V. 11. 2014. VERBI Software. Consult. Sozialforschung. GmbH, Berlin (v1.2).

[28] Mazari-Hiriart, M., Pérez-Ortiz, G., Orta-Ledesma, M.T., Armas-Vargas, F., Tapia, M.A., et al. (2014): Final opportunity to rehabilitate an urban river as a water source for Mexico City.-PlosSONE 9(7). e102081. doi: 10.1371/journal.pone.0102081

[29] Maass, M. (2012): El manejo sustentable de socio-ecosistemas. - In: Calva J.L. (coord) Cambio climático y políticas de desarrollo sustentable, Tomo 14 de la colección Análisis Estratégico para el Desarrollo, Juan Pablos Editor-Consejo Nacional de Universitarios, México.

[30] Maass, M., Equihua, M. (2015): Earth Stewardship, Socio-ecosystems, the Need for a Transdisciplinary Approach and the Role of the International Long Term Ecological Research Network (ILTER). -In: R. Rozzi, F. S. Chapin III, J. B. Callicott, S. T. A. 
Pickett, M. E. Power, J. J. Armesto, and R. H. May Jr. (Eds.). Earth Stewardship: Linking ecology and ethics in theory and practice. Springer, Dordrecht. Netherlands.

[31] Molle, F., Mamanpoush, A. (2012): Scale, governance and the management of river basins: A case study from central Iran. -Geoforum 43: 285-294.

[32] Neuman, W.L. (2000): Social Research Methods: Qualitative and Quantitative Approaches, 4ta ed. Allyn and Bacon, Boston.

[33] Olsson, P., Folke, C. (2001): Local ecological knowledge and institutional dynamics for ecosystem management: a study of Lake Racken watershed, Sweden. -Ecosystems 4: 85-104.

[34] Ostrom, E. (1991): Governing the Commons: The Evolution of Institutions for Collective Action, Cambridge. -Cambridge University Press.

[35] Programa Universitario de Estudios sobre la Ciudad-Gobierno del Distrito Federal (PUEC-UNAM-GDF). (2008): Plan Maestro de Manejo Integral y Aprovechamiento Sustentable de la Cuenca del río Magdalena, Distrito Federal. Diagnóstico Integral. 90 p. Available: http://www.sma.df.gob.mx/sma/links/dowload/biblioteca/diagnostico_integral. pdf

[36] Programa Universitario de Estudios de la Ciudad-Universidad Nacional Autónoma de México (PUEC-UNAM-GDF). (2009): "Propuesta de diagnóstico integrado de la cuenca del río Magdalena." En Plan Maestro de Manejo Integral y Aprovechamiento Sustentable de la Cuenca del río Magdalena. SMA-GDF-PUEC, UNAM. Available: http://www.sma.df.gob.mx/sma/links/download/archivos/sistema_indicadores.pdf

[37] Raymond, C.M., Fazay, I., Reed, M.S., Stringer, L.C., Robinson, C.M., Evely, A.C. (2010): Integrating local and scientific knowledge for environmental management. Journal of Environmental Management 91: 1766-1777.

[38] Robertson, A.H., McGee, T.K. (2003): Applying local knowledge: the contribution of oral history to wetland rehabilitation at Kanyapella basin, Australia. -Journal of Environmental Management 69: 275-287.

[39] Secretaría de Desarrollo Agrario Territorial y Urbano (SEDATU). (2012): Boletin No. 66 Dirección General de Comunicación Social mayo 13. México D.F. México.

[40] Schteingart, M., Salazar, C.E. (2005). Expansión urbana, sociedad y ambiente. El caso de la Ciudad de México. México Distrito Federal. -El Colegio de México.

[41] Silvano, R.A.M., Udvardy, S., Ceroni, Farley, J. (2005): An ecological integrity assessment of a Brazilian Atlantic forest watershed based on surveys of stream health and local farmers' perceptions: implications for management. -Ecological Economics 53: 369-385.

[42] Softonic V. 13. 2004. SPSS ${ }^{\circledR} 13.0$ Brief Guide. United State of America. http://brain.mcmaster.ca/SPSS.manual/SPSS\%20Brief\%20Guide\%2013.0.pdf

[43] Starkl, M., Bisschops, I., Essl, L., López, E., Martínez, J.L., Murillo, D., Nanninga, T.A. (2013): Opportunities and constrains for resource efficient environmental management in rapidly developing urban areas: the example of Mexico City. -Aquatic Procedia 1:100119.

[44] Swatuk, L.A., Motsholapheko, M. (2008): Communicating integrated water resources management: From global discourse to local practice - Chronicling an experience from the Boteti River Sub-basin, Botswana. -Physics and Chemistry of the Earth 33: 881-888.

[45] Taylor, B., Loë, R.C. (2012): Conceptualizations of local knowledge in collaborative environmental governace. -Geoforum 43: 1207-1217.

[46] Terer, T., Muthama, M.A., Dahdouh-Guebas, F., Ndiritu, G.G., Triest, L. (2012): Integrating local ecological knowledge and management practices of an isoleted semiarid papyrus swamp (Loboi-Kenya) into a wider conservation framework. -Journal of Environmental Management 93:71-84. 
[47] Varley, A. (1985): La zona urbana ejidal y la urbanización de la Ciudad de México. Revista de la Metrópoli Mexicana VI (15): 71-95.

[48] Wall, D. (2014): The Commons in History Culture, Conflict and Ecology. -The MIT Press, Cambridge, Massachusetts, London, England (History for a Sustainable Future).

[49] Wigle, J. (2010): The Xochimilco model for managing irregular settlements in conservation land in Mexico City. -Cities 27: 337-347.

[50] Wohl, E. (2006): Human impacts to mountain streams. -Geomorphology 79:217248. http://dx.doi.org/10.1016/j.geomorph.2006.06.020 